\title{
The sea anemone genus Actinostola Verrill 1883: variability and utility of traditional taxonomic features, and a re-description of Actinostola chilensis McMurrich 1904
}

Published online: 16 February 2005

(C) Springer-Verlag 2005

\begin{abstract}
Species of the genus Actinostola are known for high variability of features. Anatomy, histology and cnidae of type specimens of five species from South America and Antarctica originally described as members of Actinostola and one species of Stomphia were compared to specimens of Actinostola chilensis collected during this study. None of these traditionally used features clearly distinguish the examined Actinostola species. I therefore propose new distinctive taxonomic features, including in vivo and in situ data. I provide an emended diagnosis of the genus Actinostola and a revised list of its species. I accept the synonymy of $A$. excelsa, $A$. pergamentacea and $A$. intermedia with $A$. crassicornis, and reject the synonymy of $A$. chilensis with $A$. crassicornis and $A$. intermedia. I re-describe $A$. chilensis in detail, including in situ information. Specimens of $A$. chilensis inhabit exposed positions of
\end{abstract}

Electronic Supplementary Material Supplementary material is available in the online version of this article at http://dx.doi.org/ $10.1007 / \mathrm{s} 00300-004-0712-3$

The publisher regrets that during copy-editing of this article the names of the authors of species were styled incorrectly. Therefore, it was decided to publish this erratum which, due to the nature of the paper, contains the whole original article, but now with the names of species authors styled correctly.

The online version of the original article can be found at http:// dx.doi.org/10.1007/s00300-004-0637-x

V. Häussermann

Huinay Scientific Field Station, Chile

V. Häussermann $(\square)$

Department Biologie II,

Ludwig-Maximilians-Universität München,

Karlstr. 23-25, 80333 München, Germany

E-mail: vreni_haeussermann@yahoo.de

URL: http://www.people.freenet.de/haeussermann

Present address: V. Häussermann

Departamento de Biología Marina,

Universidad Austral de Chile, Avda. Inés de Haverbeck, casas 9,

11 y 13, Campus Isla Teja, Casilla 567, Valdivia, Chile rocky substrate from $22 \mathrm{~m}$ depth down in south Chilean fjords between Puerto Montt $\left(41^{\circ} 35^{\prime} 35^{\prime \prime} \mathrm{S}, 72^{\circ} 53^{\prime} \mathrm{W}\right)$ and Puyuhuapi $\left(44^{\circ} 31^{\prime} 36^{\prime \prime} \mathrm{S}\right.$; $\left.72^{\circ} 32^{\prime} 6^{\prime \prime} \mathrm{W}\right)$; the most conspicuous features are its relatively large size, bright-orange colour, smooth, tough column and numerous and clearly entacmaeic tentacles.

\section{Introduction}

The family Actinostolidae, with its approximately 20 genera, constitutes 1 of the 2 richest families of deepsea anemones (Fautin and Barber 1999). Due to the depths at which most of its members are collected, most species of Actinostola are collected by dredges and bottom grabs and are known primarily from fixed material (Fautin and Hessler 1989). Sampled specimens are often damaged and poorly preserved. Publications on Actinostolidae are generally scarce and widely scattered in the older literature (e.g. Hertwig 1882; Carlgren 1893, 1927, 1928; McMurrich 1893, 1904); more recently, species have been described from deepsea hydrothermal and cold vents (Fautin and Hessler 1989; Fautin and Barber 1999). Although some species of this family are known to extend to relatively shallow waters, e.g. along the Patagonian coast of Chile and Argentina, the northwest coast of North America and in the Antarctic (McMurrich 1904; Carlgren 1959; Riemann-Zürneck 1978; Fautin 1984), only two studies describing these sea anemones alive or in their habitat have been published (Ross and Sutton 1967; Ross and Zamponi 1995).

The type genus Actinostola is especially rich in species, with most of its members known from polar and subpolar regions. Species belonging to Actinostola are extremely variable in many of the features that are traditionally used as specific characteristics (Carlgren 1893, 1921; Riemann-Zürneck 1971, 1978). Riemann-Zürneck (1971) concluded that identifications based exclusively on these features, and therefore the status of most 
species, have to be treated as highly uncertain; she discerned an urgent need for new distinctive characteristics. However, the features she suggested, such as shape of preserved specimens and cnidae of unilobulate filaments, have not been adopted in subsequent studies and nor have alternative suggestions been presented (e.g. Doumenc 1984; Fautin 1984).

In the present paper, I compare type specimens of South American and Antarctic species of Actinostola, emend the diagnosis of the genus, and generate an up-todate list of its members (Appendix 1). I examine the usefulness of traditionally used morphological features, and propose new distinctive characteristics. I re-describe Actinostola chilensis from fjords in southern Chile in detail; this constitutes the first documentation of in vivo and in situ information about an identified species of Actinostola in the scientific literature.

\section{Materials and methods}

Between 1994 and 2004, Günter Försterra and I observed and examined several tens of specimens of A. chilensis along the Chilean coast from Lenca $\left(41^{\circ} 35^{\prime} 37.0^{\prime \prime} \mathrm{S}\right.$; $\left.72^{\circ} 42^{\prime} 10.9^{\prime \prime} \mathrm{W}\right)$ to Puerto Chacabuco $\left(45^{\circ} 27^{\prime} \mathrm{S}\right.$; $\left.72^{\circ} 48^{\prime} \mathrm{W}\right)$ (Fig. 1; Appendix 2) and preserved 15. Study sites are listed in Appendix 3. We studied specimens in situ by means of scuba-diving. Some specimens were kept in aquaria for several days for detailed examinations; photographs were taken both in situ and in aquaria. For preservation, specimens were relaxed with menthol crystals for $45-180 \mathrm{~min}$ and fixed in $10-15 \%$ seawater formalin. Specimens were kept in formalin for at least 4 months, before being transferred to $70 \%$ alcohol. Parts of some specimens were preserved in $96 \%$ ethanol for future molecular studies. For the histological examinations, parts of seven specimens were embedded in paraffin, sectioned at 8 and $9 \mu \mathrm{m}$, and stained with Azocarmin triple staining (Humason 1967).

I examined cnidae from three living and three preserved specimens with a light microscope $(\times 1,000$ oil immersion); these were drawn or photographed and measured. The discharge of fresh cnidae was provoked with distilled water or $4 \%$ acetic acid solution. Semipermanent slides of discharged cnidae were prepared using the technique of Yanagi (1999): a small amount of tissue is put into a drop of $4 \%$ acetic acid or $\mathrm{HCl}$ solution on a microscopic slide. After 2 or $3 \mathrm{~min}$, the liquid is drawn off carefully with a tissue. The tissue is then suspended in a solution of 1:1 seawater:glycerin that contains a few drops of phenol and formalin per $100 \mathrm{ml}$. The coverslip is applied and sealed several times with nail coating. To test the value of cnidae as distinctive characters (e.g. Fautin 1984), and especially the value of cnidae of the unilobulate filaments (e.g. Riemann-Zürneck 1978), I examined and compared the cnidae of the type material of $A$. crassicornis, A. excelsa, A. pergamentacea, A. chilensis and A. intermedia with the cnidae of a specimen of $A$. chilensis collected

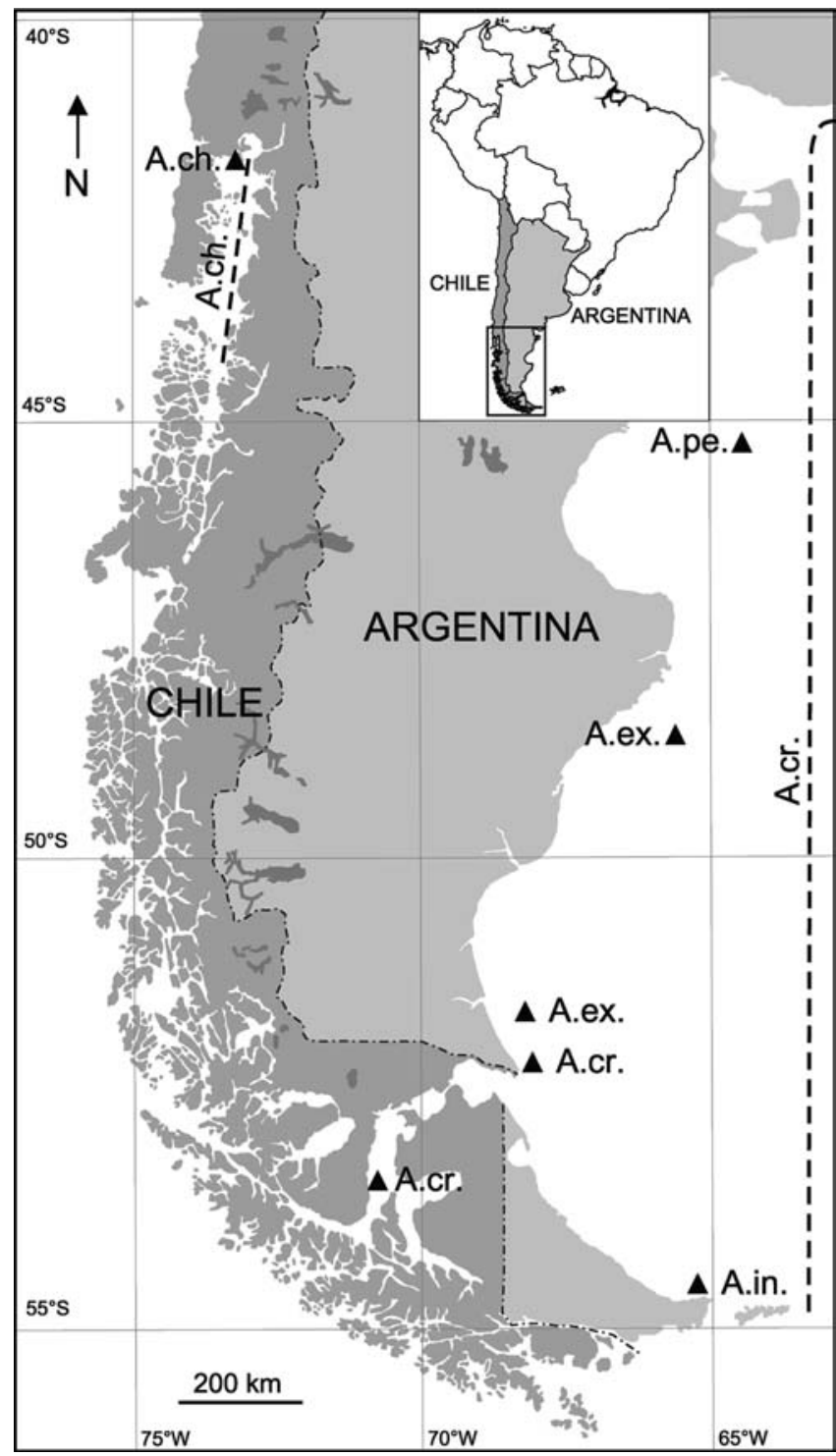

Fig. 1 Type localities and distribution of Actinostola species around southern South America [Actinostola chilensis A.ch., A. crassicornis A.cr., A. excelsa A.ex., A. intermedia A.in., A. pergamentacea A.pe.; triangles type localities, broken lines distribution of $A$. chilensis (this paper) and A. crassicornis (sensu Riemann-Zürneck 1978]

in the Chilean fjords (called A. chilensis Coll in Table 1), using type material of Stomphia selaginella as an out-group. I compared cnidae types and mean size values taking into account the standard deviation. Size ranges of cnidae are values taken from single specimens (Table 1). Nematocyst terminology follows that of England (1991).

Specimens examined

Chile

Histological slides of transverse and longitudinal sections were deposited at the Zoologische Staatssammlung 
Table 1 Size and distribution of cnidae from the type material of A. crassicornis, A. excelsa, A. pergamentacea, A. intermedia, A. chilensis and Stomphia selaginella compared with A. chilensis collected in Chile (called $A$. chilensis Coll here; for cnidae see Fig. 5) $[r$ rare (less than 10 capsules found in $1 \mathrm{~h}$ search), $f$ few (1030 capsules found in $1 \mathrm{~h}$ search), $c$ common (30-50 capsules found in $1 \mathrm{~h}$ search), $v$ very common (>50 capsules found in $1 \mathrm{~h}$ search).
" $m l$ " and " $m w$ " are the means, " $d l$ " and " $d w$ " are the standard deviations (all in $\mu \mathrm{m}$ ), " $t$ " are the number of turns on the proximal part of the tube, " $p$ " is the proportion of animals examined with respective type of cnidae present. No is the number of capsules measured. Exceptional sizes in parentheses]. Note that three $b$-mastigophores $49.5-50.4 \times 5.4-6.3 \mu \mathrm{m}$ were found in the filaments of $S$. selaginella

\begin{tabular}{|c|c|c|c|c|c|c|c|c|c|}
\hline $\begin{array}{l}\text { Tissue/cnidae type, } \\
\text { abundance }\end{array}$ & $\begin{array}{l}\text { Capsule length } \\
(\mu \mathrm{m})\end{array}$ & $m_{1}$ & $d_{1}$ & $\begin{array}{l}\text { Capsule } \\
\text { width }(\mu \mathrm{m})\end{array}$ & $m_{\mathrm{w}}$ & $d_{\mathrm{w}}$ & $t$ & $p$ & No \\
\hline \multicolumn{10}{|l|}{ Tentacles } \\
\hline \multicolumn{10}{|l|}{ Spirocysts } \\
\hline A. crassicornis $^{\mathrm{v}}$ & $18.9-52.2$ & 35.6 & 9.13 & $1.8-5.4$ & 3.7 & 0.77 & & & 40 \\
\hline A. excelsa ${ }^{\mathrm{v}}$ & $27.0-54.0$ & 38.8 & 6.46 & $2.7-5.4$ & 3.9 & 0.78 & & & 41 \\
\hline A. pergamentacea ${ }^{\mathrm{f}}$ & $18.0-46.8$ & 33.2 & 7.29 & $2.7-5.4$ & 3.9 & 0.84 & & & 45 \\
\hline A. intermedia ${ }^{\mathrm{v}}$ & (13.5) 22.3-67.5 & 42.8 & 12.8 & $1.8-5.4$ & 3.9 & 0.86 & & & 39 \\
\hline A. chilensis $^{\mathrm{c}}$ & $18.9-52.2$ & 37.2 & 9.19 & $2.7-5.4$ & 3.8 & 0.82 & & & 42 \\
\hline A. chilensis Coll $^{\mathrm{V}}(\mathrm{B})$ & $23.4-62.1$ & 42.5 & 9.44 & $2.7-5.4$ & 4.1 & 0.86 & & $6 / 6$ & 43 \\
\hline S. selaginella $\mathrm{v}$ & $24.3-51.3$ & 40.0 & 6.90 & $2.7-4.5(7.2)$ & 3.9 & 0.84 & & & 41 \\
\hline \multicolumn{10}{|l|}{ Basitrichs } \\
\hline A. crassicornis $^{\mathrm{c}}$ & $23.4-32.4$ & 28.8 & 1.84 & $2.7-4.5$ & 2.8 & 0.38 & & & 40 \\
\hline A. excelsa ${ }^{\mathrm{c}}$ & $23.4-33.3$ & 28.0 & 1.92 & $1.8-3.7$ & 2.5 & 0.44 & & & 41 \\
\hline A. pergamentacea ${ }^{\mathrm{c}-\mathrm{v}}$ & $18.9-32.4$ & 23.3 & 3.09 & $1.8-3.6$ & 2.7 & 0.24 & & & 53 \\
\hline A. intermedia ${ }^{\mathrm{c}}$ & (10.8) 24.3-34.2 & 29.1 & 3.91 & (1.35) $1.8-2.7$ & 2.3 & 0.43 & & & 72 \\
\hline A. chilensis $^{\mathrm{f}-\mathrm{c}}$ & $24.3-32.4$ & 28.3 & 2.07 & $1.8-3.6$ & 2.8 & 0.33 & & & 69 \\
\hline 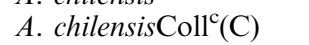 & $19.8-33.3(36.9)$ & 27.6 & 3.01 & $1.8-3.6$ & 2.7 & 0.38 & $\sim 7$ & $6 / 6$ & 66 \\
\hline S. selaginella ${ }^{\mathrm{v}}$ & $25.2-31.5$ & 28.4 & 1.35 & $1.8-2.7$ & 2.3 & 0.37 & & & 40 \\
\hline \multicolumn{10}{|c|}{ Microbasic amastigophores A } \\
\hline A. crassicornis $^{\mathrm{f}}$ & $18.0-24.3$ & 21.8 & 1.42 & $3.6-5.4$ & 4.2 & 0.56 & & & 25 \\
\hline A. excelsa ${ }^{\mathrm{c}}$ & $20.7-27.0$ & 23.6 & 1.72 & $3.2-4.5$ & 3.8 & 0.42 & & & 40 \\
\hline A. pergamentacea $\mathrm{f}$ & $18.9-24.3$ & 21.9 & 1.28 & $3.6-5.4$ & 4.5 & 0.39 & & & 29 \\
\hline A. intermedia ${ }^{\mathrm{f}}$ & $16.2-24.3$ & 21.0 & 2.22 & $3.6-5.4$ & 4.2 & 0.55 & & & 14 \\
\hline A. chilensis ${ }^{\mathrm{s}}$ & $20.7-21.6$ & & & 4.5 & & & & & 3 \\
\hline A. chilensis Coll $^{\mathrm{r}}$ (D) & $19.8-22.5$ & 21.0 & 0.86 & $3.6-4.5$ & 4.4 & 0.34 & $?$ & $5 / 6$ & 7 \\
\hline S. selaginella & - & & & - & & & & & 0 \\
\hline \multicolumn{10}{|l|}{ Large $b$-mastigophores } \\
\hline A. crassicornis & $40.5-56.7$ & 47.0 & 3.46 & $4.5-6.8$ & 5.9 & 0.55 & & & 25 \\
\hline A. excelsa ${ }^{\mathrm{f}-\mathrm{c}}$ & $36.0-52.2$ & 45.3 & 3.25 & $5.4-8.1$ & 6.5 & 0.60 & & & 41 \\
\hline A. pergamentacea* & - & & & - & & & & & 0 \\
\hline A. intermedia & $49.5-51.3$ & & & $6.3-7.2$ & & & & & 3 \\
\hline A. chilensis ${ }^{\mathrm{s}}$ & $46.8-49.5$ & & & $6.3-7.2$ & & & & $4 / 6$ & 3 \\
\hline A. chilensis Coll $^{\mathrm{r}}$ (A) & $43.0-47.0$ & & & $4.0-7.0$ & & & & & 6 \\
\hline S. selaginella & $49.5-54.9$ & & & $4.5-5.9$ & & & & & 5 \\
\hline \multicolumn{10}{|l|}{ Column } \\
\hline \multicolumn{10}{|l|}{ Basitrichs } \\
\hline A. crassicornis $^{\mathrm{v}}$ & 18.9-23.4 (33.3) & 21.4 & 2.86 & $1.8-2.7$ & 2.5 & 0.40 & & & 23 \\
\hline A. excelsa ${ }^{\mathrm{f}}$ & $18.0-22.5(28.8)$ & 20.0 & 1.66 & $1.8-2.7$ & 2.5 & 0.28 & & & 43 \\
\hline A. pergamentacea ${ }^{\mathrm{f}}$ & $17.1-21.6$ & 19.6 & 1.17 & $2.3-2.7$ & 2.6 & 0.21 & & & 45 \\
\hline A. intermedia ${ }^{\mathrm{c}}$ & $19.8-27.9$ & 23.3 & 1.81 & $1.8-2.7$ & 2.4 & 0.39 & & & 40 \\
\hline A. chilensis ${ }^{\mathrm{f}}$ & $18.0-22.5(27.9)$ & 20.4 & 1.90 & $2.7-3.6$ & 2.7 & 0.15 & & & 35 \\
\hline A. chilensis $\mathrm{Coll}^{\mathrm{c}-\mathrm{v}}(\mathrm{E})$ & $14.4-21.6$ & 18.3 & 1.54 & $2.3-3.6$ & 2.9 & 0.42 & $5-6$ & $6 / 6$ & 45 \\
\hline S. selaginella ${ }^{\mathrm{f}}$ & $18.0-22.5(29.7)$ & 20.9 & 2.26 & $1.8-3.6$ & 2.6 & 0.29 & & & 44 \\
\hline \multicolumn{10}{|l|}{ Pharynx } \\
\hline \multicolumn{10}{|l|}{ Basitrichs } \\
\hline A. crassicornis $^{\mathrm{f}}$ & (19.8) 22.5-30.6 & 26.1 & 2.68 & $1.8-3.6$ & 2.7 & 0.32 & & & 43 \\
\hline A. excelsa $a^{\mathrm{v}}$ & $18.9-27.9$ & 23.8 & 2.29 & $1.8-2.7$ & 2.6 & 0.26 & & & 52 \\
\hline A. pergamentacea ${ }^{\mathrm{c}}$ & (18.0) 22.5-28.8 & 24.5 & 2.28 & $1.8-2.7$ & 2.5 & 0.29 & & & 46 \\
\hline A. intermedia ${ }^{\mathrm{c}}$ & (18.9) $24.3-31.5$ & 28.7 & 2.36 & $1.8-2.7$ & 2.5 & 0.37 & & & 43 \\
\hline A. chilensis $^{\mathrm{f}}$ & $18.0-27.0(28.8)$ & 25.3 & 2.60 & $2.3-3.6$ & 2.9 & 0.38 & & & 48 \\
\hline A. chilensis $\operatorname{Coll}^{\mathrm{c}}(\mathrm{F})$ & (16.2) 22.5-28.8 & 26.9 & 2.49 & $2.3-3.6$ & 2.8 & 0.26 & $5-7$ & $6 / 6$ & 42 \\
\hline S. selaginella type $1^{\mathrm{f}}$ & $17.1-24.3$ & 20.3 & 1.91 & $1.8-2.7$ & 2.3 & 0.34 & & & 41 \\
\hline S. selaginella type $2^{\mathrm{c}}$ & $28.8-36.0$ & 31.7 & 1.86 & $1.8-2.7$ & 2.6 & 0.21 & & & 42 \\
\hline \multicolumn{10}{|c|}{ Microbasic amastigophores A } \\
\hline A. crassicornis $^{\mathrm{s}}$ & $18.9-23.4$ & 21.7 & 1.83 & $4.5-5.4$ & 4.8 & 0.33 & & & 8 \\
\hline A. excelsa & $19.8-25.2(27.0)$ & 22.4 & 1.59 & $3.6-5.4$ & 4.6 & 0.54 & & & 40 \\
\hline A. pergamentacea ${ }^{\mathrm{f}}$ & $20.7-24.3$ & 22.4 & 0.95 & $3.6-5.4$ & 4.2 & 0.51 & & & 25 \\
\hline A. intermedia ${ }^{\mathrm{c}}$ & $19.8-25.2$ & 22.7 & 1.57 & $4.5-5.4$ & 5.0 & 0.46 & & & 33 \\
\hline A. chilensis $^{\mathrm{f}}$ & $18.0-24.3$ & 21.2 & 1.98 & $4.5-6.3$ & 5.5 & 0.59 & & & 22 \\
\hline A. chilensis $\mathrm{Coll}^{\mathrm{c}}(\mathrm{G})$ & $17.1-24.3$ & 21.7 & 1.46 & $4.1-5.4$ & 4.8 & 0.39 & $\sim 7$ & $6 / 6$ & 38 \\
\hline S. selaginella & $22.5-25.2$ & 24.5 & 0.93 & $3.6-4.5$ & 4.2 & 0.40 & & & 8 \\
\hline
\end{tabular}


Table 1 (Contd.)

\begin{tabular}{|c|c|c|c|c|c|c|c|c|c|}
\hline $\begin{array}{l}\text { Tissue/cnidae type, } \\
\text { abundance }\end{array}$ & $\begin{array}{l}\text { Capsule length } \\
(\mu \mathrm{m})\end{array}$ & $m_{1}$ & $d_{1}$ & $\begin{array}{l}\text { Capsule } \\
\text { width }(\mu \mathrm{m})\end{array}$ & $m_{\mathrm{w}}$ & $d_{\mathrm{w}}$ & $t$ & $p$ & No \\
\hline \multicolumn{10}{|l|}{ Mesenterial filaments } \\
\hline \multicolumn{10}{|l|}{ Basitrichs } \\
\hline A. crassicornis $^{\mathrm{c}}$ & $18.9-33.3$ & 24.7 & 3.93 & $2.3-3.2$ & 2.6 & 0.25 & \multirow{7}{*}{$4-6$} & \multirow{7}{*}{$6 / 6$} & 61 \\
\hline A. excelsa ${ }^{\mathrm{f}}$ & $18.0-33.3$ & 26.3 & 4.04 & $1.8-3.2$ & 2.4 & 0.43 & & & 59 \\
\hline A. pergamentacea & $18.9-34.2$ & 26.1 & 3.74 & $1.8-2.7$ & 2.3 & 0.37 & & & 68 \\
\hline A. intermedia ${ }^{\mathrm{f}}$ & $18.9-36.0$ & 23.2 & 4.26 & $1.8-3.6$ & 2.6 & 0.59 & & & 51 \\
\hline A. chilensis $^{\mathrm{f}}$ & $17.1-26.1$ & 21.3 & 2.70 & $1.8-3.6$ & 2.7 & 0.48 & & & 16 \\
\hline A. chilensis $\operatorname{Coll}^{\mathrm{f}}(\mathrm{J})$ & $18.0-27.0(35.0)$ & 22.8 & 2.25 & $2.3-3.6$ & 3.0 & 0.38 & & & 41 \\
\hline S. selaginella ${ }^{\mathrm{f}}$ & $16.2-21.6$ & 18.3 & 1.42 & $1.4-2.7$ & 1.8 & 0.31 & & & 39 \\
\hline \multicolumn{10}{|c|}{ Microbasic amastigophores A } \\
\hline A. crassicornis $^{\mathrm{f}}$ & $19.8-24.3$ & 22.6 & 1.33 & $3.6-6.3$ & 5.0 & 0.60 & & & 38 \\
\hline A. excelsa ${ }^{\mathrm{c}}$ & $20.7-28.8$ & 25.2 & 1.61 & $3.6-5.4$ & 4.4 & 0.44 & & & 40 \\
\hline A. pergamentacea ${ }^{\mathrm{v}}$ & $20.7-26.1$ & 23.6 & 1.22 & $3.6-5.4$ & 4.5 & 0.36 & & & 41 \\
\hline A. intermedia ${ }^{\mathrm{c}}$ & $18.9-25.2$ & 23.0 & 1.38 & $4.5-6.3$ & 5.1 & 0.59 & & & 40 \\
\hline A. chilensis $^{\mathrm{v}}$ & $18.0-24.3$ & 20.9 & 1.71 & $4.5-6.3$ & 5.0 & 0.49 & & & 43 \\
\hline A. chilensis $\mathrm{Coll}^{\mathrm{c}}(\mathrm{K})$ & $18.9-22.5$ & 20.7 & 1.09 & $4.1-5.4$ & 4.7 & 0.33 & $\sim 7$ & $6 / 6$ & 41 \\
\hline S. selaginella ${ }^{\mathrm{c}}$ & $18.9-24.3$ & 21.8 & 1.31 & $3.2-5.4$ & 4.0 & 0.54 & & & 41 \\
\hline \multicolumn{10}{|l|}{$p$-mastigophores } \\
\hline S. selaginella - type $1^{\mathrm{c}}$ & (36.9) 48.6-61.2 & 52.5 & 3.65 & $3.6-5.0$ & 4.2 & 0.44 & & & 41 \\
\hline S. selaginella - type $2^{\mathrm{c}}$ & $78.3-88.2$ & 82.4 & 3.16 & $5.9-8.1$ & 6.5 & 0.46 & & & 33 \\
\hline \multicolumn{10}{|l|}{ Pedal disc } \\
\hline \multicolumn{10}{|l|}{ Basitrichs } \\
\hline A. crassicornis $^{\mathrm{f}}$ & $18.0-23.4(27.0)$ & 20.8 & 1.57 & $1.8-2.7$ & 2.5 & 0.30 & & & 43 \\
\hline A. intermedia ${ }^{\mathrm{c}}$ & $17.1-24.3(30.6)$ & 23.1 & 2.46 & $1.8-3.2$ & 2.2 & 0.42 & & & 51 \\
\hline A. chilensis $^{\mathrm{c}}$ & $17.1-20.7$ & 18.9 & 0.90 & $1.8-2.7$ & 2.4 & 0.33 & & & 41 \\
\hline A. chilensis $\mathrm{Coll}^{\mathrm{c}}(\mathrm{H})$ & $17.1-20.7$ & 19.4 & 1.08 & $1.8-2.7$ & 2.5 & 0.31 & $5-7$ & $3 / 3$ & 42 \\
\hline \multicolumn{10}{|l|}{ Spirocysts } \\
\hline A. crassicornis & - & - & - & - & - & - & & & 0 \\
\hline A. intermedia ${ }^{\mathrm{r}}$ & $26.1-54.0$ & 38.0 & 8.43 & $2.7-4.5$ & 3.8 & 0.75 & & & 12 \\
\hline A. chilensis $^{\mathrm{f}}$ & $25.2-45.0$ & 35.2 & 5.69 & $2.7-5.4$ & 4.1 & 0.99 & & & 20 \\
\hline A. chilensis $\mathrm{Coll}^{\mathrm{f}}(\mathrm{I})$ & $29.7-54.0$ & 45.2 & 8.75 & $2.7-6.3$ & 4.8 & 1.14 & & & 11 \\
\hline
\end{tabular}

*A. pergamentacea: tentacles very badly preserved and decomposed

Munich (ZSM), at the Museum für Naturkunde of the Humboldt-Universität zu Berlin (ZMB Cni 14227), as well as at the Naturhistoriska Riksmuseet Stockholm (SMNH-56586-56588 and SMNH-56595). A. chilensis [all collected by G. Försterra (GF) and V. Häussermann (VH)]; Punta Chaica, Seno Reloncaví (S53), 24 January 2000, $25 \mathrm{~m}$ (Ex. 284=ZSM 20030420); 22/24 January 2001, 22-30 m (Ex. 1, 2, 4, 5=ZSM 20030421); Punta Llonco, fjord Comau (S60a), 11 April 2003, 28 m (ZSM 20030422); Caleta Gonzalo, fjord Reñihue (S61), 16 February 1998, 27 m (Ex. 253, 254=ZSM 20030423); 20 January 2000, $33 \mathrm{~m}$ (Ex. 267=ZSM 20030424); 24 March 2001, 25-33 m (Ex. 281=ZSM 20030425); 7 February 2001, $35 \mathrm{~m}$ (Ex. 230, 231=ZSM 20030426); Caleta Gonzalo (S63), 19 January 2000, 25-30 m (Ex. $259=$ ZSM 20030427); S of Puyuhuapi (S90) 10 January 2000, 22-30 m (Ex. 233, $234=$ ZSM 20030428).

Examined type material (for localities see Appendix 4): A. chilensis McMurrich 1904, hermaphroditic (histological sections prepared); Calbuco, Chile, $41^{\circ} 45^{\prime} \mathrm{S}$, $65^{\circ} 13^{\prime} \mathrm{W}$ (coordinates from Microsoft Encarta 2002) 2937 m, (holotype ZMB Cni 4204); A. intermedia Carlgren 1899, male (histological sections prepared), Cabo San Vicente, Tierra del Fuego, Argentina, SW Atlantic, $274 \mathrm{~m}, 54^{\circ} 37^{\prime} \mathrm{S} ; 6^{\circ} 13^{\prime} \mathrm{W}$ (coordinates from Microsoft Encarta, 2002) (holotype SMNH-1184); A. crassicornis
(Hertwig 1882), fertile, SW Atlantic, $52^{\circ} 20^{\prime} \mathrm{S}, 68^{\circ} 0^{\prime} \mathrm{W}$, $101 \mathrm{~m}$ (station 313 ), and $53^{\circ} 38^{\prime} \mathrm{S}, 70^{\circ} 56^{\prime} \mathrm{W}, 18-27 \mathrm{~m}$ (station 312) (paratypes SMNH-1183 and British Museum of Natural History 1889.11.25.3-4, 9 and 10); A. excelsa McMurrich 1893, fertile, SW Atlantic, $48^{\circ} 37^{\prime} \mathrm{S}, 65^{\circ} 46^{\prime} \mathrm{W}$ and $51^{\circ} 34^{\prime} \mathrm{S}, 68^{\circ} 0^{\prime} \mathrm{W}, 92-106 \mathrm{~m}(\mathrm{Na}-$ tional Museum of Natural History, syntypes US NMNH-17780); A. pergamentacea McMurrich 1893, fertile, SW Atlantic, $45^{\circ} 22^{\prime} \mathrm{S}, 64^{\circ} 20^{\prime} \mathrm{W}, 94 \mathrm{~m}$ (station 2769) (syntypes US NMNH-17779); A. georgiana Carlgren 1927, fertile, Antarctic, $54^{\circ} 29.3^{\prime} \mathrm{S}, 3^{\circ} 43.9^{\prime} \mathrm{W}, 567 \mathrm{~m}$ (syntype SMNH-4015); A. clubbi Carlgren 1927, fertile, Oates Land, Antarctic, $67^{\circ} 21^{\prime} 46^{\prime \prime} \mathrm{S}, 155^{\circ} 21^{\prime} 10^{\prime \prime} \mathrm{W}, 464 \mathrm{~m}$ (holotype SMNH-4009); S. (Cymbactis) selaginella (Stephenson 1918), one fertile, histological sections available (1918.8.16.8), Ross Sea, Antarctic (BMNH syntype 1918.5.12.15, and 1918.5.12.31-33). For original drawings, see Fautin (2003).

Sampling sites where I found but did not collect A. chilensis (see Fig. 1; Appendix 2; for a detailed description of sites see Appendix 3): S53: $41^{\circ} 38^{\prime} 15,5^{\prime \prime} \mathrm{S}$; $72^{\circ} 40,8,3^{\prime \prime} \mathrm{W} ; \quad \mathrm{S} 57: 41^{\circ} 40.353^{\prime} \mathrm{S}, 7^{\circ} 39.399^{\prime} \mathrm{W} ; \mathrm{S} 60 \mathrm{c}$ : $42^{\circ} 09^{\prime} 36^{\prime \prime} \mathrm{S} ; \quad 72^{\circ} 26^{\prime} 06^{\prime \prime} \mathrm{W} ; \quad$ S60d: $\quad 42^{\circ} 19^{\prime} 40^{\prime \prime} \mathrm{S}$; $72^{\circ} 27^{\prime} 04^{\prime \prime} \mathrm{W}$; S60a: $42^{\circ} 20^{\prime} 28^{\prime \prime} \mathrm{S} ; \quad 72^{\circ} 26^{\prime} 54^{\prime \prime} \mathrm{W} ; \quad$ S60f: $42^{\circ} 23^{\prime} 15^{\prime \prime} \mathrm{S} ; \quad 72^{\circ} 27^{\prime} 38^{\prime \prime} \mathrm{W} ; \quad \mathrm{S} 61: \quad 42^{\circ} 32^{\prime} 46,6^{\prime \prime} \mathrm{S}$; $72^{\circ} 37^{\prime} 0,2^{\prime \prime} \mathrm{W}$; S 62: $42^{\circ} 33^{\prime} \mathrm{S}, 72^{\circ} 36^{\prime} \mathrm{W}$; S63: 42 ${ }^{\circ} 33^{\prime} 12,7^{\prime \prime} \mathrm{S}$; 
$72^{\circ} 35^{\prime} 22,3^{\prime \prime} \mathrm{W} ; \quad \mathrm{S} 65: \quad 42^{\circ} 33,494^{\prime} \mathrm{S} ; \quad 72^{\circ} 36,271^{\prime} \mathrm{W} ; \quad \mathrm{S} 83$ : $43^{\circ} 47^{\prime} 09,1^{\prime \prime} \mathrm{S}, \quad 72^{\circ} 55^{\prime} 34,2^{\prime \prime} \mathrm{W} ; \quad \mathrm{S} 85: \quad 43^{\circ} 58^{\prime} 18,4^{\prime \prime} \mathrm{S}$, $73^{\circ} 07^{\prime} 00,6^{\prime \prime} \mathrm{W} ; \quad \mathrm{S} 90$ : $44^{\circ} 31,608^{\prime} \mathrm{S} ; \quad 72^{\circ} 32,107^{\prime} \mathrm{W} ; \quad \mathrm{S} 96$ : $45^{\circ} 26^{\prime} 47,9^{\prime \prime} \mathrm{S} ; 72^{\circ} 49^{\prime} 25,8^{\prime \prime} \mathrm{W}$ (identification uncertain).

\section{Results}

Family: Actinostolidae Carlgren 1932; Genus: Actinostola Verrill 1883

Diagnosis after Carlgren (1949), with changes in bold: Actinostolidae with body sometimes short, sometimes cup-like, sometimes long, cylindrical. Column usually thick, firm, slightly rugose to smooth, or with flat tubercles produced by mesogloeal thickenings. Sphincter mesogloeal; upper part of column can completely cover tentacles. Tentacles short to medium-sized, inner considerably longer than outer; sometimes with mesogloeal thickenings on aboral sides at the base; outside at tips may be provided with microbasic $b$-mastigophores. Longitudinal muscles of tentacles mesogloeal; radial muscles of oral disc endodermal to mesogloeal. Two welldeveloped siphonoglyphs each connected to a pair of directive mesenteries. Mesenteries hexamerously arranged. The two mesenteries in one and the same pair, from third or fourth cycle, irregularly arranged, but as a rule orientated so that the mesentery that turns its longitudinal muscle towards the nearest mesentery of the preceding cycle is more developed than its partner. Retractors of mesenteries diffuse, parietobasilar and basilar muscles strong. Mesenteries of two first cycles sterile.

Cnidae: spirocysts (in tentacles, may be found in pedal disc), basitrichs (in all tissues), microbasic $b$-mastigophores (may be found in tentacles or rarely in filaments), microbasic amastigophores $\mathrm{A}$ (in tentacles, pharynx and filaments). Type species: Actinostola (Urticina) callosa (Verrill 1882)

Re-description of Actinostola chilensis McMurrich 1904

Locality in parentheses if new material was collected.
External anatomy

\section{Differential diagnosis}

Bright-orange, medium to large-sized with pedal-disc diameter up to $80 \mathrm{~mm}$, contracted animals shaped like cylindrical stump of cone, with crater-like hole at apex. Column smooth, without distinct fosse; up to more than 200 tentacles, outer considerably longer than inner, mouth opening prominent (Fig. 2). Preserved specimens white to slightly beige (Fig. 3). Hermaphroditic or with separate sexes. Cnidae and internal anatomy similar to that of other species of Actinostola. Specimens of A. crassicornis from Argentina and specimens of A. georgiana from Antarctica can be distinguished from $A$. chilensis by the common presence of embryos in the gastrocoel in A. crassicornis and A. georgiana.

\section{Size}

In life, pedal-disc diameter (to $80 \mathrm{~mm}$ ); column diameter (to $50 \mathrm{~mm}$ ); column height (to $100 \mathrm{~mm}$ ); oral-disc diameter (to $85 \mathrm{~mm}$ ); longest tentacles $40 \mathrm{~mm}$; (preserved) pedal-disc diameter (to $65 \mathrm{~mm}$ ); column diameter (to $60 \mathrm{~mm}$ ); column height to $45 \mathrm{~mm}$; oral-disc diameter to $65 \mathrm{~mm}$; longest tentacles $37 \mathrm{~mm}$. Pedal-disc diameter of most preserved specimens between 40 and $60 \mathrm{~mm}$, much smaller individuals very rare.

\section{Oral disc and tentacles}

Oral disc round, insertions of mesenteries visible. Mouth opening central, distinctly prominent, round to triangular, lips thick. Pharynx deeply furrowed, with two distinct siphonoglyphs ending in distinct grooves. Up to more than 200 tentacles on outer half of oral disc, hexamerously arranged in up to seven cycles, last cycle may be incomplete. Tentacles medium-sized to long, longer than radius of oral disc, strongly entacmaeic, outer tentacles very short, conical, each with slightly rounded tip and with distal cinclis. Tentacles in preserved state short to medium-sized (Fig. 3), without mesogloeal thickening at base.
A. chilensis

A. chilensis McMurrich

Non A. chilensis McMurrich

Non A. intermedia

A. intermedia Carlgren

? A. intermedia Carlgren

Non A. intermedia Carlgren

Non Catadiomene intermedia Carlgren

? A. callosa Verrill

Line missing
McMurrich 1904, p 247 (Calbuco, Chile)

Stephenson 1920, p 557; Carlgren 1949, p 78

Clubb 1908, p 4 (Antarctica); Pax 1926

(Ross Sea, Antarctica); Fautin 1984, p 14 (Antarctica)

Carlgren 1899, p 31 (Tierra del Fuego, Argentina, Atlantic)

Carlgren 1959, p 29 (Seno Reloncavi and Golfo de Ancud, Chile);

Sebens and Paine 1979, p 230

Doumenc 1984, p 150 (Los Vilos to Coquimbo, northern Chile)

Carlgren 1927, p 58; Carlgren 1949, p 78; Riemann-Zürneck 1971,

p 161; Riemann-Zürneck 1978, p 66; Fautin 1984, p 14 (Antarctica)

Stephenson 1920, p 558

McMurrich 1893, p 167 (between Ecuador and Galapagos Islands) 

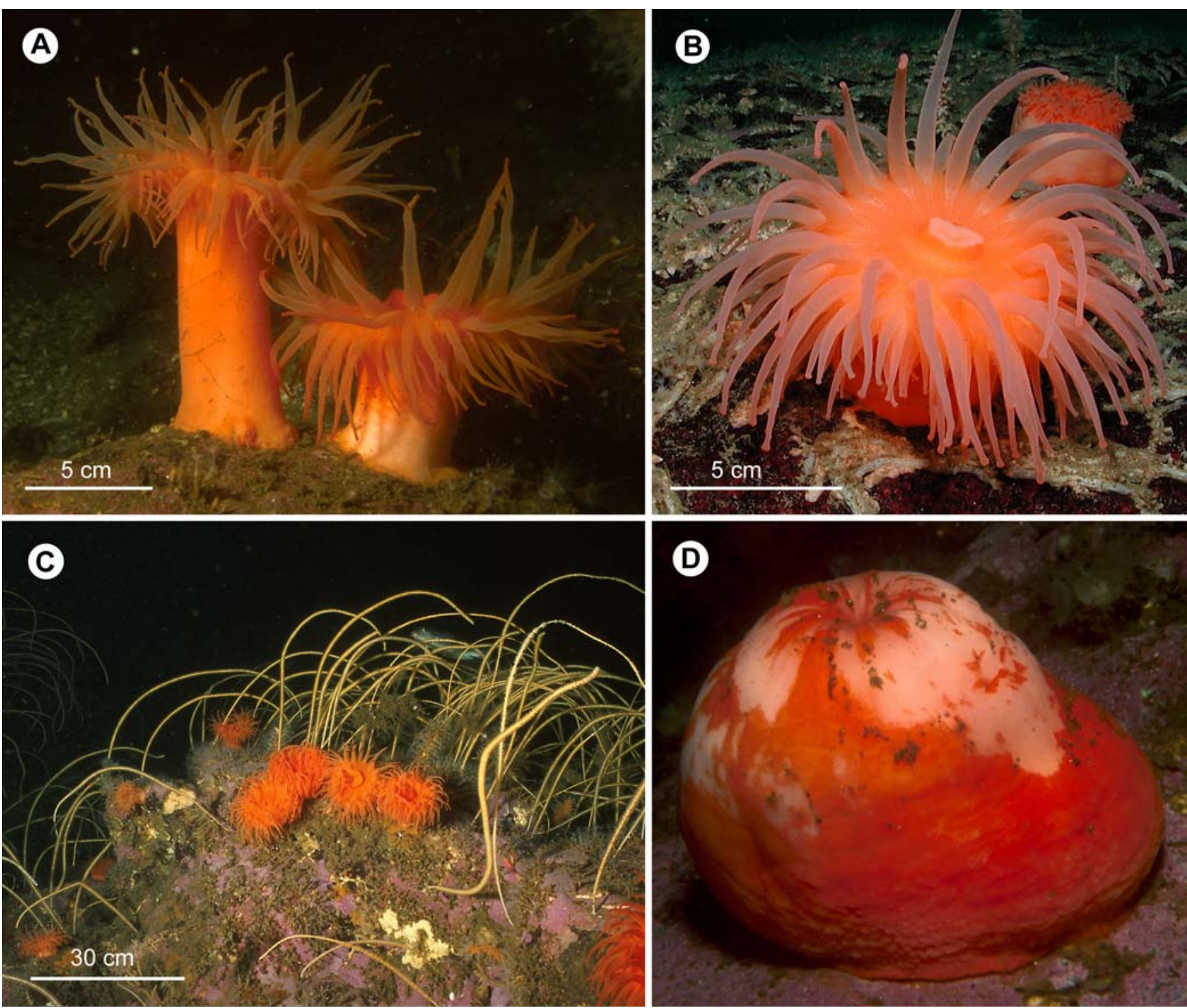

Fig. 2a-d Specimens of Actinostola chilensis in situ. a Lateral view column of two specimens; note posture of tentacles; fjord Reñihue, $32 \mathrm{~m}$. b Oral view oral disc and tentacles; note insertions of mesenteries; fjord Comau, $25 \mathrm{~m}$. c Group of specimens in a "meadow" of Primnoella sp.; Seno Reloncaví, 28 m. d Lateral view completely contracted specimen; note spots with missing ectodermal tissue; Seno Reloncaví, 28 m; real size

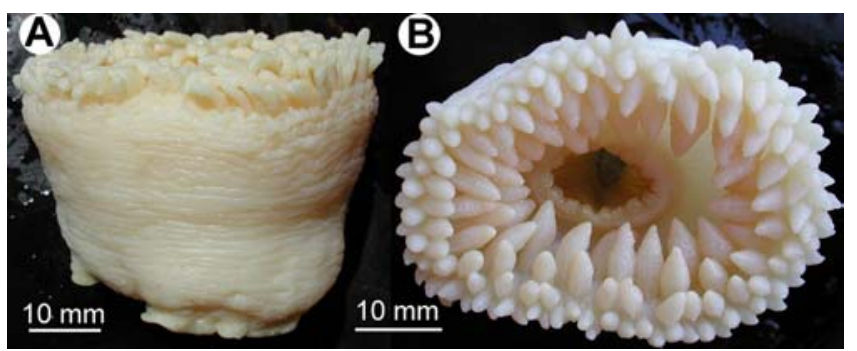

Fig. 3a,b Preserved specimens of Actinostola chilensis. a Lateral view, b Oral view

\section{Column}

As broad as high or higher than broad; proximally slightly and distally strongly trumpet-like when expanded. Generally smooth, thick and firm; slightly tuberculate in large animals. Insertions of mesenteries visible as fine longitudinal lines. Margin tentaculate, no distinct fosse.

\section{Pedal disc}

Well developed, round, relatively thin. Limbus smooth. Insertions of mesenteries visible.

\section{Colouration}

Oral disc orange, slightly darker around the pharynx, lips and pharynx light-orange, separated from oral disc by a clear line; insertions of mesenteries visible as lighter lines. Tentacles orange, column bright-orange, rarely 
reddish-orange, in some large animals with white patches due to missing ectodermal tissue; most proximal region in some animals lighter, in others limbus slightly darker than rest of column.

\section{Variability}

Colour and appearance in situ of specimens in the Chilean fjord region very uniform (Fig. 2), bright-orange; some specimens with white spots on column due to scraped-off ectodermal tissue (Fig. 2d). Carlgren (1959) described his specimens as pink, salmon-coloured to bright-orange.

\section{Internal anatomy}

\section{General}

Mesenteries hexamerously arranged in up to seven cycles, first two (in one small individual) or three cycles perfect. Mesenteries numerous and thin, more than 200. Mesenteries from fourth cycle onward arranged according to the Actinostola rule (Fig. 4g,h). Oral stoma present in most perfect mesenteries; marginal stoma may be present in larger perfect mesenteries. Actinopharynx approximately half length of column, with deep longitudinal furrows proximally. Pharynx with two very broad, proximally strongly prolonged siphonoglyphs which nearly reach pedal disc and roll up at end. Two pairs of short directives, connected to the siphonoglyphs (Fig. 4f). Four of 15 specimens fertile, 2 male and 2 female. Because of the hermaphroditism of the holotype (Fig. 4h,i), the species has to be defined as "hermaphroditic or with separate sexes". Diameter of eggs 225$480 \mu \mathrm{m}$ (in type of A. chilensis and ZSM 20030421) (Fig. 4g-i) $50-110 \mu \mathrm{m}$ respectively (ZSM 20030420). Fourth to sixth cycle, rarely third cycle fertile, youngest cycles sterile; on younger cycles often only stronger mesentery of a pair fertile. Two oldest cycles of mesenteries and directives sterile. No evidence of asexual reproduction.

\section{Musculature}

Sphincter (Fig. 4a-d) mesogloeal, long, reticulated or in layers, in marginal region approximately $1 / 3-2 / 3$ (in some specimens up to $100 \%$ ) breadth of mesogloea, either of constant breadth along the column (Fig. 4a,c) or strongly tapering proximally (Fig. 4b,d). Circular musculature of body wall hardly visible, endodermal to mesogloeal, arranged in layers. Longitudinal muscles of tentacles strong, mesogloeal (Fig. 4e). Circular muscles of oral disc endodermal to endo-mesogloeal. Mesenterial retractors diffuse, thin, of equal breadth along mesentery (Fig. 4f-h). Basilar muscles and parietobasilar muscles strong; latter forms distinct fold in proximal-most region of mesenteries (Fig. 4g)
Fig. 4a-i Actinostola chilensis. a,b Longitudinal sections through marginal region. c,d Details of sections through mesogloeal marginal sphincter. e Cross section through tentacle. f,g Cross section through mesenteries at level of stomadaeum. h,i Type material of A. chilensis: $\mathbf{h}$ cross section through mesenteries at stomadaeum level, $\mathbf{i}$ ova and sperm (directives $d i$, ectoderm $e c$, pair of imperfect mesenteries im, mesogloea $m$, mesenterial filaments $m f$, mesogloeal longitudinal muscle of tentacle $m t$, ova $o$, parietobasilar muscle $p b$, lumen of actinopharynx $p h$, pair of perfect mesenteries $p m$, retractor muscle $r$, reticulated pad $r p$, sperm $s$, siphonoglyph $s i$, mesogloeal sphincter $s p$ )

\section{Epithelia}

Mesogloea very thick, up to $65 \mathrm{~mm}$ measured (column); ectoderm very thin compared to mesogloea (Fig. 4f). Batteries of spirocysts visible in tentacle ectoderm; acidophil inclusions in ectoderm of column and filaments. Siphonoglyphs with strongly developed reticulated pads (Fig. 4f).

\section{Cnidae}

Spirocysts (in tentacles), basitrichs (in all tissues), microbasic $b$-mastigophores (in filaments, and in some specimens in tentacles), microbasic amastigophores A (in pharynx, filaments, tentacles) (Fig. 5a-k). See Table 1 for information on size and distribution of cnidae.

Additionally, I found rare, exceptional cnidae in single specimens: eight large basitrichs $49.5-63.9 \times 3.6-$ $4.5 \mu \mathrm{m}$ in the distal column, three $b$-mastigophores 24.3 $25.2 \times 4.1-6.3 \mu \mathrm{m}$ in the filaments of $A$. chilensis; four $b$-mastigophores $40.5-51.3 \times 5.4-6.3 \mu \mathrm{m}$ in the column and three $b$-mastigophores $80 \times 11 \mu \mathrm{m}$ in the filaments of A. chilensis Coll.

The basitrichs of the unilobate filaments varied in shape from an elongated capsule of equal breadth (Fig. $5 \mathrm{~J}_{1}$ ) to a capsule that narrows towards both ends (Fig. $5 \mathrm{~J}_{3}$ ); the length of the shaft varied from half (Fig. $5 \mathbf{J}_{2}$ ) to the full length (Fig. $5 \mathbf{J}_{1}$ ) of the capsule. In the filaments of a preserved specimen of $A$. chilensis Coll, a fired cnida which looked like a $p$-mastigophore B with a short "Faltstück" was found.

The tubule of fired microbasic amastigophores A of

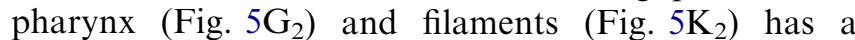
proximally thickened shaft equal in length to the remainder of the tubule.

\section{Distribution and zoogeography of Actinostola chilensis}

A. chilensis can be found in more or less protected bays and fjords of the northern part of the Chilean fjord region from Seno de Reloncaví $\left(41^{\circ} 35^{\prime} 35^{\prime \prime} \mathrm{S}, 72^{\circ} 53^{\prime} \mathrm{W}\right)$ to the fjord Puyuhuapi $\left(44^{\circ} 31,608^{\prime} \mathrm{S} ; 7^{\circ} 32,107^{\prime} \mathrm{W}\right)$ (Fig. 1, Appendices 2 and 3). I commonly found this species in the Golf of Reloncaví (S53, S57), as well as in 


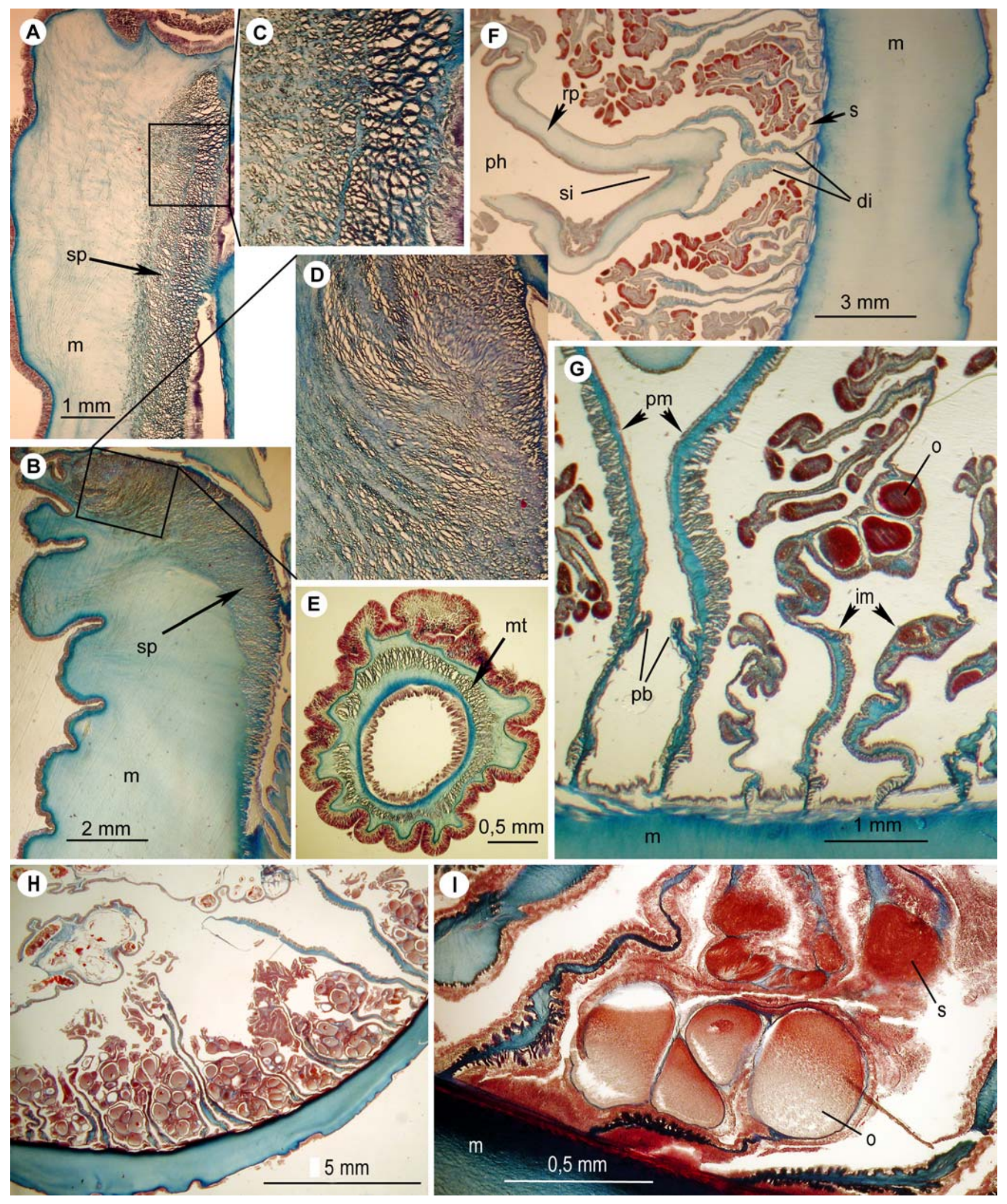

the fjords Comau (S60) and Reñihue (S61-65), somewhat less commonly in the fjord Puyuhuapi (S90) and around Raul Marin Balmaceda (S83, S85); I did not find it along the exposed coasts around Bahia Tic Toc
(S77-S82). Dirk Schories (in litt. 2004) found it around Melinka Island (S84a). While diving, I observed one specimen in the fjord Chacabuco (S96), which probably belonged to the same species. However, in contrast to 
all the other specimens examined, it was salmon-coloured rather than orange. Most probably, A. chilensis can be found further south than the fjord Puyuhuapi, at least to Peninsula Taitao $\left(46^{\circ} 30^{\prime}-46^{\circ} 57^{\prime} \mathrm{S}\right)$. This large peninsula divides the Patagonian Province and is considered a zoogeographical barrier (Lanzellotti and Vasquez 1999; Häussermann 2004). I found this species as shallow as $22 \mathrm{~m}$, but more frequently between 32 and $45 \mathrm{~m}$; Carlgren (1959) stated that the range extends to $278 \mathrm{~m}$.

\section{Natural history of Actinostola chilensis}

A. chilensis is a very eye-catching species that can be found in exposed positions on rocky substrate attached to bare rock (Fig. 2c; Appendix 5A), generally on the edge of terraces or on top of elevations, but never under overhangs (Fig. 2) and never with its oral disc downward. One specimen was found attached to the axis of a gorgonian of the genus Primnoella Gray 1858 (Appendix 5B). Specimens can be found either individually or, in favourable spots such as rocky elevations, in aggregations of up to 15 individuals, in some cases touching one another (Fig. 2a,c). During our survey, water temperature in the habitat of $A$. chilensis ranged from approximately $6^{\circ} \mathrm{C}$ in winter to approximately $11^{\circ} \mathrm{C}$ in summer; salinity was approximately $31 \%$. In the fjords, surface water to depths of $8 \mathrm{~m}$ is often brackish, with minimum salinities lower than 10\% ; tidal amplitudes are up to $7.3 \mathrm{~m}$ (data measured in 2003 in Comau fjord at Huinay Scientific Field Station).

Most specimens we observed were fully expanded in a typical position with the inner tentacles directed upward and the outer tentacles sideward (Fig. 2; Appendix 5ac); in current, the oral disc points downstream. Some specimens were slightly or completely contracted, covering the tentacles with the column (Fig. 2d). In Chilean
Fig. 5 Cnidae of Actinostola chilensis. Letters $A-K$ correspond to cnidae listed in Table 1 (Tentacles $A$ large $b$ mastigophore, $B$ spirocyst, $C$ basitrich, $D$ microbasic amastigophore A; Column E basitrich; Pharynx $F$ basitrich, $G$ microbasic amastigophore A; Pedal disc $H$ basitrich, $I$ spirocyst; Filaments $J$ basitrich, $K$ microbasic amastigophore A)

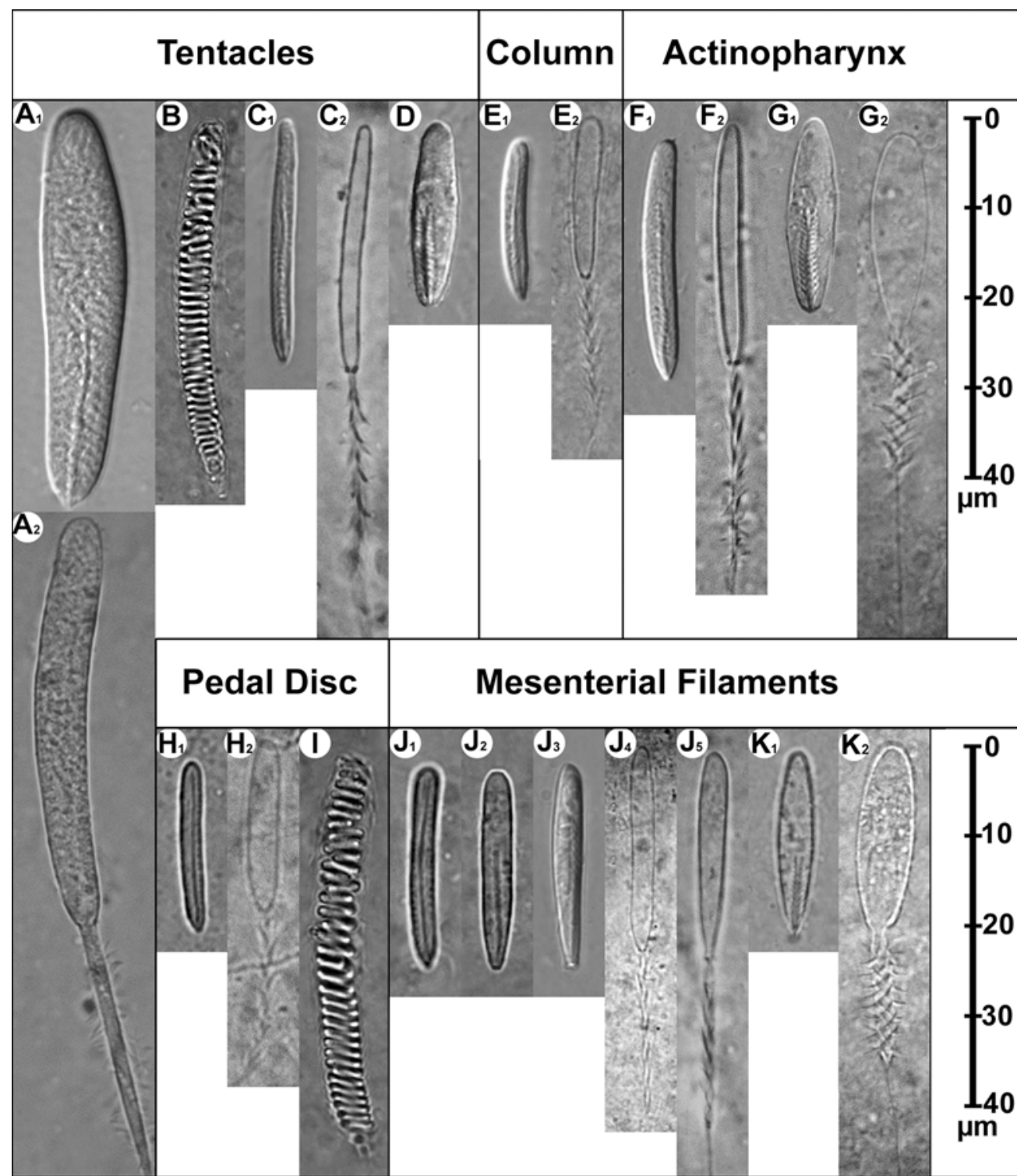


fjords, I regularly found $A$. chilensis associated with the gorgonian Primnoella sp. (Fig. 2c; Appendix 5B), with the giant brachiopod Magellania venosa (Dixon 1789) (Appendix 5C) and in the vicinity of the azooxanthellate coral Desmophyllum dianthus (Esper, 1794) (Försterra and Häussermann 2003).

Specimens of $A$. chilensis are easy to collect by scuba diving because they come off the substratum readily and without injury. When disturbed, animals completely contract. Tentacles are sticky to the touch. In the aquarium, specimens need 1 to several days to reattach, requiring well-oxygenated, salty (non-superficial) water with considerable current and, ideally, darkness before they resume their in situ appearance. In unsuitable conditions, they protrude the pharynx, eject food and change position, e.g. by somersaults over the oral disc. They can quickly and strongly change their shape, e.g. from long trumpet-shaped over vase-or cup-shaped to an almost perfect sphere. A. chilensis relaxes readily with menthol, but extended exposure to this anaesthetic results in maceration of tissue and reduction in sensitivity of cnidae to fire.

\section{Discussion}

\section{Generic description of Actinostola}

The proposed emendations to the diagnosis of Actinostola correct errors in its definition. One of the main errors is the statement that the animals cannot fully cover the tentacles with the column; this characteristic was erroneously used to distinguish Actinostola from Stomphia (Carlgren 1949). However, I found that living specimens of $A$. chilensis are capable of fully covering the tentacles with the column, and do so regularly (Fig. 2d). I propose to delete the phrase "tentacles never more numerous than the mesenteries at the base": of 13 specimens I examined, only 3 had fewer tentacles than mesenteries at the base, and 9 had more; 1 had as many tentacles as mesenteries at the base. Mesenteries are numerous and thin and thus hard to count. I could not confirm the presence of numerous perfect mesenteries: in the examined specimens, generally 24 of approximately 100 pairs were perfect; in other species, up to 48 pairs may be perfect. None of these emendations conflict with the description of the type species A. callosa (Appendix 6).

Carlgren (1928) erected the genus Paractinostola based on only minor differences between it and Actinostola: more tentacles than mesenteries at the pedal disc and a more or less lobed oral disc. I agree with Riemann-Zürneck (1978) that both features may be present in large members of some species of Actinostola and concur with her synonymy of these genera. Sensu Carlgren's (1949) generic identification key for the family Actinostolidae, Ophiodiscus and Stomphia (Appendix 7A) are the only remaining genera within group IA, which is characterized by possessing "mesenteries distinctly arranged according to the Actinostola-rule". The genus Ophiodiscus (Hertwig 1882) contains the two species, Ophiodiscus annulatus and O. sulcatus, from deep waters off North Chile; neither has been found since the beginning of the twentieth century. In Ophiodiscus, mesenteries are divided into macro- and micronemes, and tentacles are arranged in a single corona. Stomphia is distinguished from Actinostola by its cnidae (see Table 1), by having a central rise on the pedal disc, and 16 perfect, fertile mesenteries, and by always lacking thickenings on the outer base of the tentacles (for in vivo photographs see Appendices 5 and 7).

Taxonomic characteristics to distinguish Actinostola species

Riemann-Zürneck (1971, 1978) showed that the following characteristics that had been used to denominate species of Actinostola were very variable within A. callosa: marginal stomata, tentacular $b$-mastigophores, thickenings at the outer base of the tentacles, thickenings of the oral disc, and thickness of tentacular mesogloea. The size and structure of the marginal sphincter vary across the genus, but variation is more dependent on the size of the specimens (Fig. 4a-d) than on taxonomy, varying only slightly between species (Riemann-Zürneck 1971, 1978).

Riemann-Zürneck (1978) suggested the cnidae of the unilobate filaments might distinguish species: she found a second, smaller basitrich in those of $A$. crassicornis that was lacking in $A$. intermedia. I have examined type material of these species and did not find differences in the cnidae of the unilobate filaments (Table 1). In examining numerous filaments of the specimens I collected, I noticed that the basitrichs of these filaments vary in shape and shaft length (see Fig. 5J) and that some (Fig. $5 \mathbf{J}_{2}, \mathbf{J}_{5}$ ) resemble the microbasic $p$-mastigophores of the filaments of some actiniid anemones. I observed intermediate stages of shape and shaft length (Fig. 5 $\mathbf{J}_{3}$ ), and thus could not distinguish distinct types of cnidae. From my data, I conclude that neither types nor sizes of cnidae are useful for distinguishing the examined species. However, since fired cnidae reveal more distinctive features than unfired ones, I have provided photographs of fired cnidae from $A$. chilensis (Fig. 5), which could serve a comparative purpose in the future if fired cnidae are examined for other species in the genus.

Riemann-Zürneck (1978) proposed size and shape of the preserved specimens as an additional feature, if a large number of well-preserved specimens were available. The specimens I have examined showed extreme variability in shape, and a single specimen may take the shape of all described forms within minutes in the aquarium. Due to the fact that the form of the preserved specimens strongly depends on the state of relaxation, I reject this feature as a species-level characteristic. 
Since preserved specimens of different Actinostola species are extremely similar in anatomy and in the shape, size and distribution of cnidae (Riemann-Zürneck 1978), the distinction of species has to be based on other characteristics, such as reproductive mode (e.g. brooded embryos in the gastrocoel, hermaphroditism), texture of the column or range of variability in morphological features (e.g. maximum pedal-disc diameter, maximum thickness of the columnar mesogloea, presence or absence of tentacular thickenings or marginal stomata in all specimens from different depths). However, to detect these features, several specimens are needed. This is problematic because many species of Actinostola are only known from a few specimens. In addition, many type specimens are more than 100 years old and, at least in the case of some South American species, are in rather poor condition. Thus additional information is necessary to clarify species boundaries; this additional information may include zoogeographic, in situ and in vivo information. For a well-founded distinction of the species of Actinostola found in subAntarctic and Antarctic waters, it will be necessary to collect, examine and re-describe in detail specimens of Argentinean and Antarctic species of Actinostola. In situ and in vivo characteristics such as appearance (e.g. length of tentacles or posture), variability of colour, ecological niche, position in the habitat, mobility in the aquarium and behaviour (e.g. reaction to disturbance) that distinguish the species of Actinostola might be useful to complete the few existing distinguishing characteristics so that species can be defined and an identification key can be made (for an example, see Appendix 6). This re-description of $A$. chilensis is a first step and should be used as a comparative base for future work.

Synonymization of South American and Antarctic species of Actinostola

Eight species of Actinostola have been described from southern South America and Antarctica (Fig. 1; Appendices 4 and 8). Several of these were later synonymized: Carlgren (1927) synonymized $A$. chilensis with $A$. intermedia; Riemann-Zürneck (1978) synonymized A. excelsa and A. pergamentacea with A. crassicornis, and Fautin (1984) additionally included $A$. intermedia and $A$. clubbi in the synonymy list of $A$. crassicornis, making this species the most abundant and wide-spread species of Actinostola in the southern hemisphere (Fig. 1; Appendix 8). Riemann-Zürneck (1978) and Fautin (1984) provided discussions of the rationale for these synonymies, but because they were based exclusively on anatomical and cnidae data of questionable distinctive value for preserved specimens, they should be reconsidered.

Riemann-Zürneck (1978) found that approximately half of the specimens of $A$. crassicornis had embryos in the gastrocoel. In contrast, none were found in any of the type specimens of its putative synonyms $A$. excelsa (three specimens), A. pergamentacea (five specimens),
A. intermedia (one specimen), A. chilensis (one specimen) or $A$. clubbi (one specimen). Fautin (1984) regularly found brooded young in the many USARP specimens from Antarctic and sub-Antarctic waters that she examined (Appendix 8). But since she assigned all specimens from all locations to A. crassicornis based on characteristics that are of minor distinctive value, her description might refer to a species complex. The anatomy and cnidae of preserved specimens of $A$. intermedia, $A$. excelsa and $A$. pergamentacea do not differ from those of $A$. crassicornis. Due to the lack of distinctive features and because of their overlapping distribution, I accept the synonymy of $A$. excelsa, $A$. pergamentacea and $A$. crassicornis. The fact that no embryos were found in the few type specimens of $A$. excelsa and A. pergamentacea is not proof that members of these species do not brood young. However, a possible cooccurrence of brooding and non-brooding species of Actinostola along the Argentinean shelf and the extension of $A$. crassicornis into the Antarctic Ocean require further investigation.

I reject the synonymy between the Chilean species A. chilensis and the Argentinean species A. crassicornis. Neither Carlgren (1959), McMurrich (1904), nor I found brooded young in any specimens of $A$. chilensis collected in different regions, years and seasons in the fjords of southern Chile. The holotype of $A$. chilensis is hermaphroditic, a unique characteristic among species of Actinostola from South America. These differences in the reproductive mode in combination with possible the zoogeographical barriers such as the Peninsula Taitao and the Strait of Magellan (Riemann-Zürneck 1986; Lancellotti and Vásquez 1999) lead me to recognize A. chilensis as a distinct species. A. chilensis is distinct from several species of Actinostola found in the Antarctic Ocean and in Argentina; it differs significantly in in vivo appearance, colour and texture of the column (Rodriguez, in litt. 2003; Roux, in litt. 2003).

I accept the synonymy of $A$. intermedia and $A$. crassicornis, but reject the synonymy of $A$. intermedia and $A$. chilensis for zoogeographical reasons: the type locality of $A$. intermedia was erroneously described as "Cabo San Vicente, Strait of Magellan" (Carlgren 1899) and was therefore claimed to be in Chile. However, the only "Cabo San Vicente" in this region is situated on the Atlantic coast of Argentina, in Tierra del Fuego (Fig. 1), a locality that lies within the known range of $A$. crassicornis. This separates the localities where specimens of the Argentinean and Chilean species were found by more than 1,000 kilometres and by zoogeographical barriers.

Comparison of cnidae within South American species of Actinostola

The cnidom of $S$. selaginella is clearly distinct from that of the examined species of Actinostola: it lacks amastigophores $\mathrm{A}$ in the tentacles, and includes two types of 
basitrichs in the pharynx and two types of microbasic $p$-mastigophores in the filaments (Table 1). Taking into account the standard deviation and the differences in sizes of the examined specimens, the sizes of the following cnidae do not differ significantly among the species of Actinostola I compared: spirocysts and basitrichs of tentacles and all cnidae of column, pharynx and filaments. The differences between mean values were approximately equal to the standard deviations and thus not useful to distinguish species. Spirocysts are distributed patchily and thus were not encountered on every slide made from tissue of the pedal disc of specimens of $A$. chilensis (both type and Coll) or $A$. intermedia. The cnidae of the Chilean specimens differ from those of the Argentinean ones in minor details: the microbasic amastigophores A of the tentacles and $b$-mastigophores of the filaments are scarcer, but have the same average sizes. The basitrichs of the unilobate filaments of all of the Argentinean species show a very broad size range, and there was no evidence for two distinct size groups as proposed by Riemann-Zürneck (1978); the mean value is very similar in all species of Actinostola examined (Table 1).

Further records of Actinostola species along the west coast of South America

Two other species identified as Actinostola have been reported from the west coast of South America. Doumenc (1984) identified specimens collected from 350 to $450 \mathrm{~m}$ depth off central Chile, $30^{\circ}-32^{\circ} 31^{\prime} \mathrm{S}$, as $A$. intermedia (which was at the time considered a synonym of A. chilensis). McMurrich (1893) identified specimens from 717 to $1,484 \mathrm{~m}$ depth between Ecuador and Galapagos Islands, $0^{\circ} 24^{\prime}-0^{\circ} 37^{\prime} \mathrm{S}$ as $A$. callosa. McMurrich (1893) considered the last species to be widely distributed and synonymous with $A$. crassicornis; Carlgren (1927) rejected this synonymization, assigning the specimens from Ecuador to A. crassicornis rather than to A. callosa, all other specimens of which are known from the North Atlantic. Zoogeographical transition areas such as the region between Coquimbo and Valparaíso, central Chile and around Paita, Peru (Brattström and Johanssen 1983; Lancellotti and Vásquez 1999; Sullivan Sealey and Bustamante 1999) are supposed to exist between the sites where I found A. chilensis and the two other records further north along the west coast of South America. However for some species, generally of deep waters, these barriers may not apply. The abovementioned species descriptions do not offer enough information for a well-founded identification, and an examination of the specimens is necessary for a final decision if these specimens belong to $A$. chilensis. Therefore the records have to be treated as uncertain.

Acknowledgements I am particularly grateful to Günter Försterra for his company and great help with diving and sampling during the field trips, and to Meg Daly for very detailed and constructive comments. Many thanks to Kensuke Yanagi for very helpful remarks. Many thanks also to Björn Sohlenius, Carsten Lüter and Stephen Cairns for the loan of type material, to Karin Riemann for lending a field microscope and to Estefanía Rodriguez for helpful discussions. Thanks go to Gerhard Haszprunar for providing material, space and continuous support; to Carlos Gallardo, Alejandro Bravo, Elena Clasing and Wolfgang Stotz for their friendly support, and to Heide Felske for making available a wonderful map. Many thanks go to the Huinay Foundation for a scholarship for lodging, food and working space in the marine biology station in Comau fjord, and to Rose and Fritz Häussermann for their manifold and continued help. This publication is drawn from the doctoral thesis of the author, supported by 2 oneyear governmental scholarships "Förderung des wissenschaftlichen und künstlerischen Nachwuchses" and "Förderung der Promotion von Wissenschaftlerinnen" from the LMU Munich, and by a oneyear HSP III scholarship from the DAAD. This is publication number 2 of the Huinay Scientific Field Station.

\section{References}

Brattström H, Johanssen A (1983) Ecological and regional zoogeography of the marine benthic fauna of Chile. Report No. 49 of the Lund University Chile Expedition 1948-49. Sarsia 68:289339

Carlgren O (1893) Studien über Nordische Actinien. K Sven Vetenskapsakad Handl 25:1-148

Carlgren O (1899) Zoantharien. Hamb Magelh Sammelr 4:1-48

Carlgren O (1921) Actiniaria I. Dan Ingolf Exped 5:1-241

Carlgren O (1927) Actiniaria and Zoantharia. In: Odhner T (ed) Further zoological results of the Swedish Antarctic Expedition 1901-1903. PA Norstedt and Söner, Stockholm, pp 1-102

Carlgren O (1928) Actiniaria der Deutschen Tiefsee-Expedition. Wiss Ergebn Dtsch Exped 22:125-266

Carlgren O (1932) Die Ceriantharien, Zoantharien und Actiniarien des arktischen Gebietes In: Römer F, Brauer A, Arndt W (eds) Eine Zusammenstellung der arktischen Tierformen mit besonderer Berücksichtigung des Spitzbergen-Gebietes auf Grund der Ergebnisse der Deutschen Expedition in das Nördliche Eismeer im Jahre 1898. Fischer, Jena, pp 255-266

Carlgren O (1949) A survey of the Ptychodactiaria, Corallimorpharia and Actiniaria. K Sven Vetenskapsakad Handl, Fjärde Ser 1:1-121

Carlgren O (1959) Reports of the Lund University Chile Expedition 1948-49 38. Corallimorpharia and Actiniaria with description of a new genus and species from Peru. Lunds Univ Årsskr N F Avd 2 56: 1-39

Clubb JA (1908) Coelentera. National Antarctic Expedition 19011904 Natural History IV. Actiniae:1-12

Dixon G (1789) A voyage around the world; but more particularly to the north-west coast of America: performed in 1785, 1786, 1787, and 1788, in the King George and Queen Charlotte, Captain Portlock and Dixon. London, pp 1-360

Doumenc D (1984) Les actinies bathyales du Chili: un exemple d'utilisation de fichiers informatiques. Ann Inst Oceanogr 60:143-162

England KW (1991) Nematocysts of sea anemones (Actiniaria, Ceriantharia and Corallimorpharia: Cnidaria): nomenclature. In: Williams RB, Cornelius PFS, Hughes RG, Robson EA (eds) Coelenterate biology: recent research on cnidaria and ctenophora. Kluwer, Belgium, pp 691-697

Esper EJC (1794) Fortsetzungen der Pflanzenthiere, vol 1(parts 12). Nürnberg, pp 1-64

Fautin DG (1984) More Antarctic and Subantarctic sea anemones (Coelenterata: Corallimorpharia and Actiniaria). Biol Antarctic Seas XIV Antarct Res Ser 41:1-42

Fautin DG (2003) Hexacorallians of the world: sea anemones, Corals and their allies. http://hercules.kgs.ku.edu/hexacoral/ anemone2/index.cfm (last check:5 May 2004)

Fautin DG, Barber BR (1999) Maractis rimicarivora, a new genus and species of sea anemone (Cnidaria: Anthozoa: Actiniaria: 
Actinostolidae) from an Atlantic hydrothermal vent. Proc Biol Soc Wash 122:624-631

Fautin DG, Hessler RR (1989) Marianactis bythios, a new genus and species of actinostolid sea anemone (Coelenterata: Actiniaria) from the Mariana vents. Proc Biol Soc Wash 102:815-825

Försterra G, Häussermann V (2003) First report on large scleractinian (Cnidaria: Anthozoa) accumulations in cold-temperate shallow water of south Chilean fjords. Zool Verh Leiden 345:117-128

Gray JE (1858) Synopsis of the families and genera of axiferous Zoophytes or barked corals. Proc Zool Soc Lond 1857:278-294

Häussermann V (2004) Neue integrative Ansätze für das Sammeln, Bearbeiten und Beschreiben skelettloser Hexacorallia am Beispiel chilenischer Seeanemonen. Doctoral thesis, Ludwig-Maximilians-University

Hertwig R (1882) Die Actinien der Challengerexpedition. Fischer, Jena

Humason GL (1967) Animal tissue techniques. Freeman, San Francisco

Lancellotti DA, Vásquez JA (1999) Biogrographical patterns of benthic macroinvertebrates in the Southeastern Pacific littoral. J Biogeogr 26:1001-1006

McMurrich JP (1893) Scientific results of explorations by the U. S. Fish Commission Steamer Albatross. No. XXIII.-Report on the Actiniae collected by the United States Fish Commission Steamer Albatross during the winter of 1887-1888. Proc US Natl Mus 16:119-216

McMurrich JP (1904) The Actiniae of the Plate collection. Zool Jahrb 6 [suppl]:215-306

Pax F (1926) Die Aktinien der Deutschen Südpolar-Expedition 1901-1903. Dtsch Südpolar-Exped 1901-1903 18:3-62

Riemann-Zürneck K (1971) Die Variabilität taxonomisch wichtiger Merkmale bei Actinostola callosa (Anthozoa: Actiniaria). Veröff Inst Meeresforsch 13:153-162
Riemann-Zürneck K (1978) Actiniaria des Südwestatlantik IV. Actinostola crassicornis (Hertwig 1882) mit einer Diskussion verwandter Arten. Veröff Inst Meeresforsch 17:65-85

Riemann-Zürneck K (1986) Zur Biogeographie des Südwestatlantik mit besonderer Berücksichtigung der Seeanemonen (Coelenterata: Actiniaria). Helgol Wiss Meeresunters 40:91-149

Ross DM, Sutton L (1967) Swimming sea anemones of Puget Sound: swimming of Actinostola new species in response to Stomphia coccinea. Science 155:1419-1421

Ross DM, Zamponi MO (1995) A description of Stomphia pacifica sp. nov. (Anthozoa: Actiniaria) and its behavioural interactions with some asteroids. Physis Buenos Aires Secc A 50 (118119):7-12

Sebens KP, Paine RT (1979) Biogeography of anthozoans along the west coast of South America: habitat, disturbance, and prey availability. N.Z. DSIR Inf. Ser. 137. Proc Int Symp Mar Biogeogr Evol South Hem, Auckland, New Zealand

Stephenson TA (1918) Coelenterata. Part I Actiniaria. Nat Hist Rep Br Antarct ("Terra Nova") Exped 1910 5:1-68

Stephenson TA (1920) On the classification of Actiniaria. Part I Forms with acontia and forms with a mesogloeal sphincter. Q J Microsc Sci 64:425-574

Sullivan Sealey K, Bustamante G (1999) Setting Geographic Priorities for Marine Conservation in Latin America and the Carribbean. The Nature Conservancy, Arlington, Virginia

Verrill AE (1882) Notice of the remarkable Marine Fauna occupying the outer banks off the Southern coast of New England, vol 3. Am J Sci Third Ser XXIII:135-137

Verrill AE (1883) XVI Results of the explorations made by the steamer "Albatross", off the northern coast of the United States, in 1883. Rep U S Comm Fish Fisheries: 503-517

Yanagi K (1999) Taxonomy and developmental biology of Japanese Anthopleura (Anthozoa: Actiniaria). PhD Thesis, Tokyo University of Fisheries 